\title{
A Case of Endoscopic Transethmoidal Drainage of Subdural Abscess Originated from Dental Infection
}

\author{
Yangseop Noh ${ }^{1}$, Jaelim Kim ${ }^{1}$, Sang Duk Hong ${ }^{1}$, and Jung Won Choi ${ }^{2}$ \\ ${ }^{1}$ Departments of Otorhinolaryngology-Head and Neck Surgery, ${ }^{2}$ Neurosurgery, Samsung Medical Center, \\ Sungkyunkwan University School of Medicine, Seoul, Korea
}

\author{
치성 감염 이후 발생한 경막하 농양의 내시경적 경사골동 접근법을 통한 농양 제거 \\ 노양섭 $^{1} \cdot$ 김재림 $^{1} \cdot$ 홍상덕 $^{1} \cdot$ 최정원 $^{2}$ \\ 성균관대학교 의과대학 삼성서울병원 이비인후과학교실, ${ }^{1}$ 신경외과학교실 ${ }^{2}$
}

\author{
Received June 28, 2016 \\ Revised August 30,2016 \\ Accepted August 31, 2016 \\ Address for correspondence \\ Sang Duk Hong, MD \\ Department of Otorhinolaryngology- \\ Head and Neck Surgery, \\ Samsung Medical Center, \\ Sungkyunkwan University \\ School of Medicine, \\ 81 Irwon-ro, Gangnam-gu, \\ Seoul 06351, Korea \\ Tel $+82-2-3410-3579$ \\ Fax $+82-2-3410-3879$ \\ E-mailkkam97@gmail.com
}

\begin{abstract}
Subdural empyema is fulminating purulent infection that develops between the dura and the arachnoid membranes. It is rare but one of the most immediate of neurosurgical emergencies, hence the importance of proper diagnosis and early intervention. Most subdural empyema complicated in the ENT field originate from sinonasal or otologic infections rather than dental infections. In our case of 64-years-old male, who was admitted with headache and fever, the diagnosed subdural empyema originated from odontogenic parapharyngeal abscess. We report that the case was successfully managed after urgent surgical drainage by endoscopic transethmoidal approach with long term intravenous antibiotics.
\end{abstract}

Korean J Otorhinolaryngol-Head Neck Surg 2017;60(8):420-4

Key Words Dental infection · Endoscopic transethmoidal drainage

Parapharyngeal abscess · Subdural empyema.

\section{서 론}

치성 질환은 이비인후과 영역에서 많은 부분을 차지하지는 않으나 비부비동염 및 경부 심부감염의 중요한 원인 질환이 될 수 있다. 치성 질환은 크게 염증성과 비염증성으로 나뉘 며, 염증성 치성 질환은 치아의 염증과 직접적으로 관련되어 악안면 및 비부비동으로 파급된 염증성 질환을 말하며, 흔 히 치성 감염증(odontogenic infection)이라고 불린다. 치성 감 염에서 부비동염 및 안와감염, 경막하 농양, 안와 농양 등으로 전파할 수 있다. ${ }^{1}$

경막하 농양은 경막(dura)과 지주막(arachnoid) 사이 공간 에 발생하는 화농성 감염을 의미하며 신경외과적 응급 질환

This is an Open Access article distributed under the terms of the Creative Commons Attribution Non-Commercial License (http://creativecommons.org/licenses/by-nc/4.0) which permits unrestricted non-commercial use, distribution, and reproduction in any medium, provided the original work is properly cited.
중 하나이다. ${ }^{2)}$ 대개 일측성이며 국소 두개내 세균 감염의 $20 \%$ 를 차지하고 있다. ${ }^{34)}$ 일반적으로는 뇌수막염의 합병증으 로 생기는 경우가 가장 흔하며 그 외 부비동염, 중이염, 유양돌 기염의 합병증 등의 원인으로 인해 발생한다. ${ }^{3,5)}$ 생존률은 수 술 시의 의식 상태와 관련이 있다고 알려져 있으며, 입원 시 의 식 상태의 문제가 없는 경우 치사율은 $10 \%$ 미만이며 혼수상 태에서 치료가 시작된 경우 치사율은 $75 \%$ 에 달하는 것으로 보고되어 있다. ${ }^{34}$

경막하 농양의 경우 상기 서술한 바와 같이 부비동염, 중이 염의 합병증으로 인해 발생하는 것이 일반적이며 치성 감염에 의해 생긴 경우라 하더라도 부비동염 등의 감염을 거쳐 진행하 는 경우가 대부분이다. 치성 감염을 시작으로 하여 부비동염 등을 유발하지 않고 두개저 골수염 및 경막하 농양을 유발한 증례는 매우 드물며, 경비강 접근법으로 농양을 배액한 증례 도 매우 드물다. 
본 저자들은 치성 감염에서 시작하여 부비동염 없이 발생한 경막하 농양을 경비강 접근법으로 배액 및 항생제 치료를 통하 여 성공적으로 치료한 증례를 경험하였기에 보고하는 바이다.

\section{증 례}

64세 남자가 좌측 안면 통증 및 부종, 좌측 두통, 개구장 애(trismus)를 주소로 연고지 병원에 입원하였다. 당시 안면 부의 봉와직염 의심 하에 정맥 항생제 치료를 시작하였다. 이 후 지속되는 두통 및 고열로 뇌 자기공명영상(brain magnetic resonance imaging) 및 경부 컴퓨터단층촬영(computed tomography)을 시행하였으며 영상 소견 상 뇌 전두부의 경막하 농양, 좌측 부인두 및 턱밑 공간의 농양이 확인되어 수술적 배 농을 위하여 본원으로 전원되었다.

내원 2주 전 위궤양으로 인해 위장 출혈 및 혈변이 발생한 과거력이 있었으며, 이에 대해서는 내시경적 지혈술을 시행하 였다. 1년 전 좌측 상악 부위의 치통이 있었으나 별다른 치료 는 받지 않았다고 하며, 그 외의 특별한 과거력 및 면역 저하를 의심할 만한 과거력은 없는 환자였다. 부비동염을 의심할 만 한 증상 또한 없었다.

내원 당시 환자의 의식은 명료하였고, 혈압은 $118 / 76 \mathrm{~mm} \mathrm{Hg}$, 체온 $37.2^{\circ} \mathrm{C}$, 맥박수 64 회/분, 호흡수 16 회/분이었다. 경부 진 찰상 좌측 경부에 동통을 동반한 부종 외에는 특이소견은 없 었으며, 신경학적 진찰 상 모두 정상이었다.

내원 당시 시행한 말초혈액검사에서 백혈구수 $5920 / \mathrm{mm}^{3}$ (호중구 $68 \%$, 림프구 $22 \%$, 단핵구 $9 \%$, 호산구 $1 \%$ ), 혈색소 $7.6 \mathrm{~g} / \mathrm{dL}$, 적혈구용적률 $24.6 \%$, 혈소판 $358000 / \mathrm{mm}^{3}$ 였다. 요 검사는 정상소견을 보였으며 혈액 검사에서 적혈구 침강속도 (erythrocyte sedimentation rate) $38 \mathrm{~mm} / \mathrm{hr}$, C반응단백(Creactive protein)은 $1.52 \mathrm{mg} / \mathrm{dL}$ 로 상승한 소견을 보였다. 외
부 촬영한 뇌 자기공명영상 및 경부 전산화단층촬영에서 치 성 원인으로 인한 심경부 감염 및 뇌경막하 농양 소견이 보 였다(Figs. 1A, 2A, and B). 좌측 제2대구치의 뿌리(root) 주 위로 치조골(alveolar bone)의 골흡수(osteolysis) 소견이 관 찰되며 그 부위의 협근(buccinators muscle) 비대 및 농양이 관찰되었다. 난원공(foramen ovale) 주변의 염증 소견 및 두 개저에 직접적인 골 용해 소견을 보여(Fig. $2 \mathrm{C}$ and D), 이 부 분을 통하여 두개내로 염증이 전파된 것으로 보이며, 이로 인 해 두개저 골수염 및 경막하 농양이 발생한 것으로 추정해볼 수 있었다.

환자는 신경외과 입원 후 수액요법을 포함한 경험적 항생제 (ampicillin/sulbactam, cefotaxime, metronidazole)를 투여 하였고 비강 내 내시경적 접근법을 통한 경막하 농양 배농 및 부인두 농양 배농을 위하여 이비인후과에 협진 의뢰되었다. 좌측 경막하 농양에 대해서는 경사골동 접근법을 통해 수술 이 진행되었으며 보다 정확한 수술을 위해 Navigation 기기가 사용되었다(BRAINLAB Navigation System ${ }^{\circledR}$; BRAINLAB, Feldkirchen, Germany). ${ }^{6}$ 좌측의 상악동, 사골동, 접형동에 대해 부비동 내시경 수술을 시행한 후 후사골동 두개저(posterior ehtmoidal skull base)에 드릴을 통한 $5 \mathrm{~mm}$ 정도의 구 멍을 형성 후 배농을 시행하였고, 이후 vancomycin과 생리식 염수를 혼합하여 농양이 있던 공간에 대해 광범위 세척(vancomycin mixed saline irrigation)을 시행하였다(Fig. 3A and B). 상기 수술 과정에서 뇌척수액 유출[Cerebrospinal fluid (CSF) leak]이 발생하였으며, 이에 주변의 점막(ethmoid sinus mucosa)을 이용한 점막 재배치술(mucosal repositioning)을 통해 유출 부위를 폐쇄하였고 피판 상방으로 fibril seal$\operatorname{ant}\left(\right.$ TachoSil ${ }^{\circledR}$; Baxter, Deerfield, IL, USA) 패킹을 시행하였 다. 이후 Nasopore(Nasopore; Polyganics BV, Groningen, Netherlands)를 이용하여 비강내 패킹을 시행 후 수술을 종
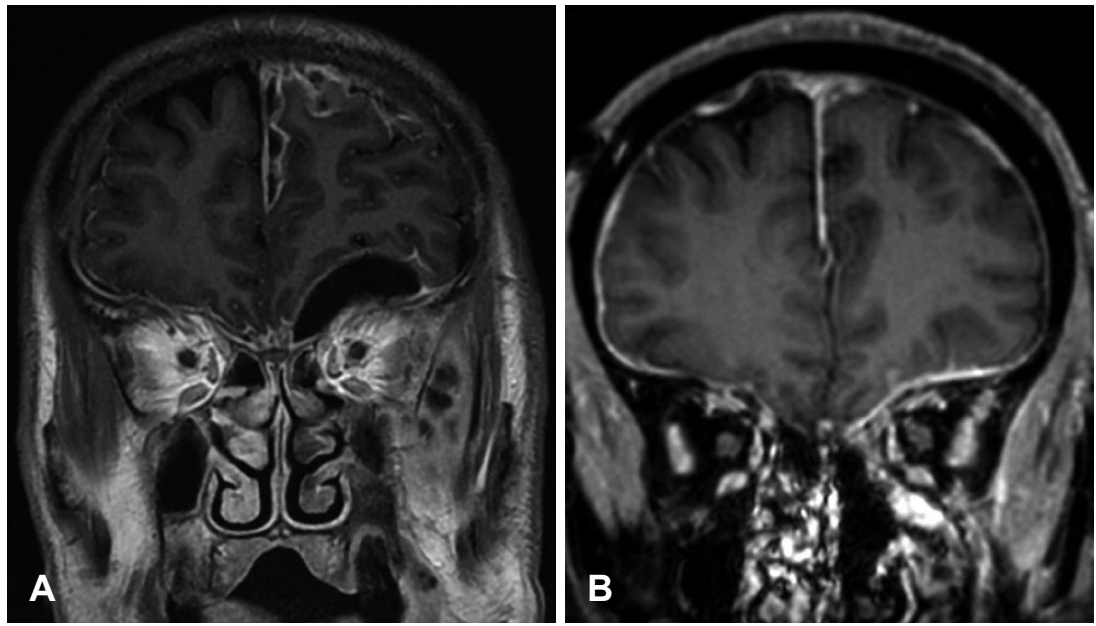

Fig. 1. Coronal imaging of the T1 contrast enhanced brain MRI. Preoperative coronal imaging of brain MRI. Subdural empyema in left frontal lobe area (A). Postoperative coronal imaging of brain MRI. After drainage, there is no definite subdural empyema in left frontal lobe (B). 

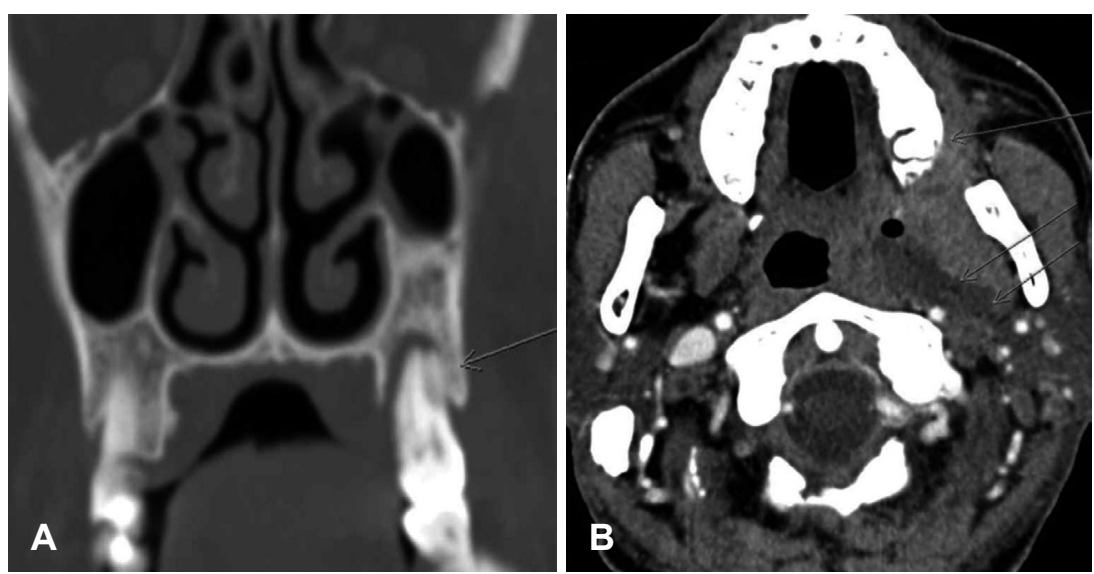

Fig. 2. Preoperative imaging of the enhanced neck CT. Osteolysis of alveolar bone surrounding root of left 2 nd maxillary molar tooth (arrow) (A). Multilobulated fluid collection (abscesses) of left parapharyngeal space behind left 2nd maxillary molar root (arrows) (B). Coronal CT showed skull base bony erosion (black arrow) suggesting direct osteomyelitis and parapharyngeal abscess (white arrow) (C). Black arrow: coronal CT showed free air adjacent to foramen ovale (black arrow)-suggesting that foramen ovale is the possible route of intracranial spread (D).
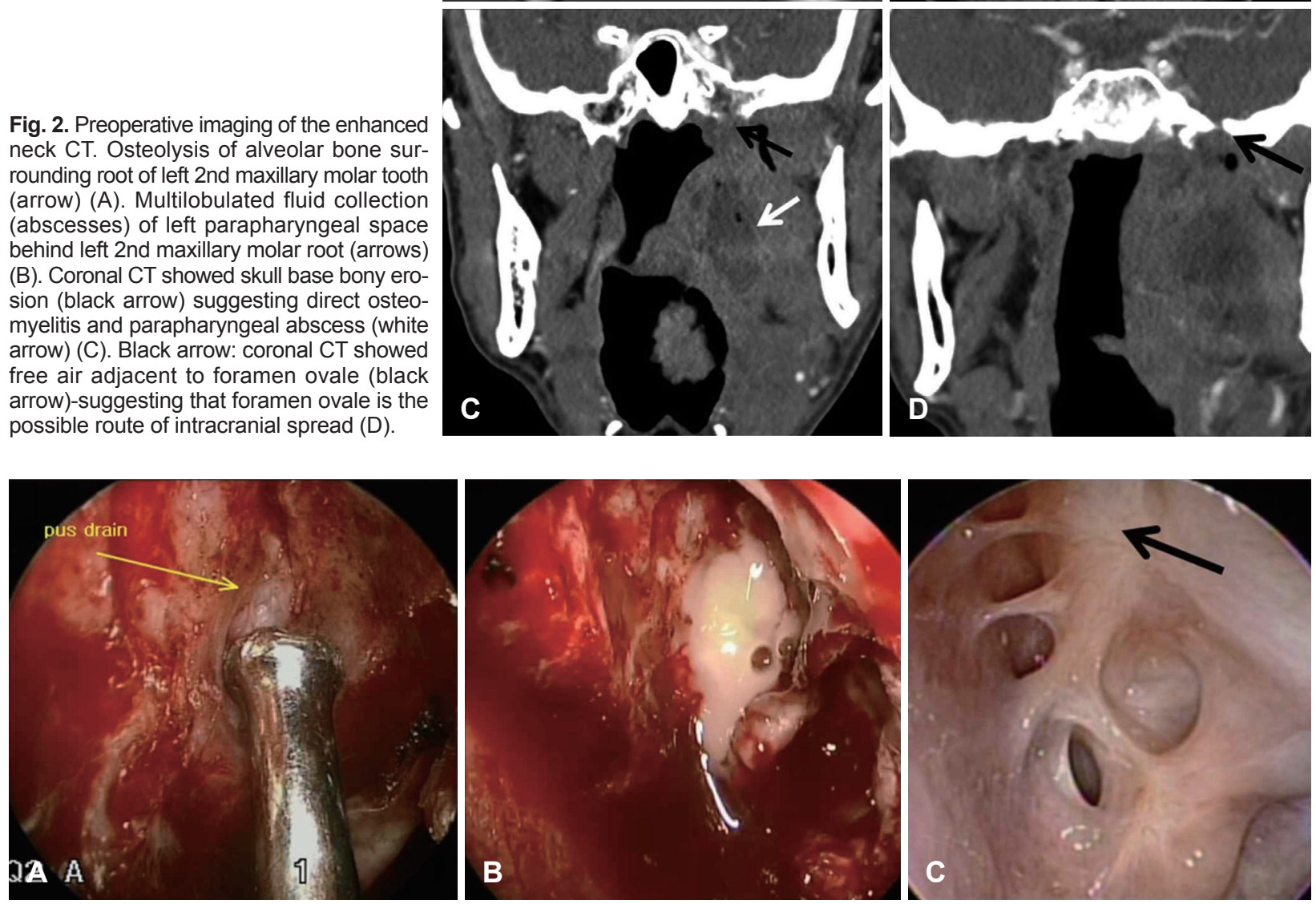

Fig. 3. These figures show operative findings. Operative image of surgical drain via posterior ethmoidal skull base. Creamy pus was drained $(A$ and $B)$. Endoscopic findings in postoperative 3 month. Well healed mucosa (black arrow) that was site of the hole for draining of subdural abscess $(C)$.

료하였다. 부인두 농양의 경우 좌측 턱밑샘(submandibular gland)의 아래쪽으로 횡절개(transverse incision) 시행 후 익 구개와(pterygopalatine space) 및 교근(masseter space) 부위 까지 접근하였으며, 경구개 접근법을 통해서도 부인두 농양 제 거를 시행하였다. 이후 베타딘 및 생리식염수를 통한 광범위 세척을 시행하였다. 농양 제거술 시행 시 치성 감염의 원인으 로 생각된 좌측 제 2 대구치 발치도 치과 협진 하에 시행되었 다. 수술 후에는 3일간 절대 침상 안정(absolute bed rest)을 시
행하였으며, 수술 후 체온은 정상 범위 내로 유지되었고 두통 또한 호전되었다. 수술 당시 채취한 농양 검체에 대하여 균배 양 검사를 시행하였으나 모두 음성이었다. 수술 1 주일 뒤 감 염내과와 상의 하에 ampicillin/sulbactam은 투여 중단하였고, cefotaxime, metronidazole만 투여하였으며 총 항생제 치료 기간은 4 6주가량 유지하기로 하였다. 수술 후 6주째까지 정 맥내 항생제를 투여하였으며, 수술 후 2개월째 뇌 자기공명 영상에서 농양이 모두 치료된 것을 알 수 있었다(Fig. 1B). 외 
래에서 수술 후 3 개월째 시행한 비부비동 내시경 소견상 뇌 척수액 비루 등 특이소견 없이 추적 관찰 중이다(Fig. 3 C).

\section{고 찰}

경막하 농양은 신경외과에서 가장 긴급한 신경학적 응급 질환 중 하나이다.") 가장 먼저 나타나는 증상은 두통이며 이 후 전신 피로, 오한, 경부강직 등으로 증상이 진행하게 된다. 이후 실어증이나 반신마비 등의 증상이 유발될 수 있으며 적절 한 치료가 이루어지지 않는다면 중첩발작(status epilepticus), 정맥동 혈전증, 뇌염 등의 더욱 심각한 질환으로 진행할 수 있으며 결국 사망에 이를 수 있다.

경막하 농양의 원인으로 만성 비부비동염, 중이염, 유양돌 기염 등이 가장 주된 원인 질환들로 알려져 있다. 두개골 수술 (cranial surgery), 두부외상 등에 이어 발생하는 경우도 있으 며 뇌수막염 이후 발생하는 경막하 삼출액(subdural effusion) 이나 혈종의 2 차 감염에 의해 생길 수도 있다고 보고되어 있 다. 그 외 안면 혹은 두피 열상, 치성 감염 등의 원인으로 경막 하 농양이 생기는 경우도 있다. 보통 치성감염에 의해 두개내 농양이 유발되는 경우 부비동염을 유발한 후 두개내 농양을 형성하거나, 혹은 혈성 전파(Hematogenous spread)에 의한 것이 대부분으로 알려져 있으나 본 증례의 경우 영상학적 소 견으로 미루어 볼 때, 좌측 제2대구치의 뿌리(root) 주위로 치 조골(alveolar bone)의 골흡수(osteolysis) 소견 및 그 부위의 협근(buccinators muscle) 비대 및 농양이 관찰되었으며 난 원공(foramen ovale) 주변의 염증 소견 및 두개저에 직접적 인 골 용해 소견을 보여 이 부분을 통하여 두개내로 염증이 전파된 것으로 보이며, 이로 인해 두개저 골수염 및 경막하 농양이 발생한 것으로 추정해볼 수 있었다. 더욱이 면역 저하 를 유발할 만한 질환을 않았거나, 면역 억제제를 복용한 과 거력 또한 없었던 건강한 남성이었다는 점에서 특이점을 가 진 증례라고 할 수 있다.

가장 흔한 원인 균주로는 혐기성 세균(anaerobic) 및 Streptococci, Staphylococci, Haemophilus influenza, 그 외 Gramnegative bacilli 등의 호기성 세균들이 알려져 있다. ${ }^{3)}$ 그 중 경막하 농양에서 가장 흔한 원인은 'Streptococcus milleri group'이며 현재는 Streptococcus anginosus group으로 명 명되어 있다. ${ }^{899}$ 본 증례에서도 이전의 항생제 치료로 인하여, 검체에 대한 균 배양 검사에서는 균주가 자라지 않았으나 bacterial rDNA identification(sequencing) 검사에서는 Streptococcus constellatus 및 Streptococcus anginosus 균이 동 정되었다.

항생제 치료는 세균 배양 검사와 항생제 감수성 검사에 따
라 투약하는 것이 좋으나, 검사가 나오기 전이나 배양검사가 명확하지 않을 경우 경험적 항생제 투여를 하게 된다. 최대한 빨리 항생제 치료를 시작하는 것이 좋으며, 혐기성 세균 및 Staphylococci, aerobic streptococci를 cover할 수 있는 항 생제를 사용하게 된다. 크기가 크지 않은 경막하 농양 $(<1.5 \mathrm{~cm}$ diameter)의 경우 항생제 단독 요법을 시행해 볼 수 있으나 빠 르게 진행하는 질환의 특성 상 항생제 단독 요법은 잘 사용 되지 않는다. 항생제는 보통 환자의 상태를 주의깊게 관찰하 며 3 6주 사용하는 것이 일반적이다. ${ }^{10)}$ 본 증례에서도 본원 내원 후 6주간 경험적 항생제를 사용하였다.

수술적 배농 또한 중요한 치료이며, 경막하 농양에서 첫번 째 선택은 개두술을 통한 농양 제거이다. 적절한 노출 및 탐 색, 광범위한 제거를 위해 가장 적절한 방법으로 알려져 있으 며 그 외 천두술(burr hole opening)을 통한 배농도 시도해 볼 수 있다. ${ }^{11)}$ 그 외 전두엽 등의 선택적인 위치에 발생한 경막 하 농양의 경우 내시경을 통한 경사골동(transethmoidal approach) 혹은 경접형동 접근법(trans-sphenoidal approach)을 시도해 볼 수 있으며, 개두술에 비해 수술 범위가 크지 않고, 술 후 회복이 빠른 장점이 있다. 본 증례의 경우 내시경을 통 한 경사골동 접근법을 이용하여 전두엽의 경막하 농양으로 접 근 후 성공적으로 배농을 시행하였다.

경막하 농양의 사망률의 경우 적절한 진단과 치료(항생제 및 수술적 배농)로 인해 점차적으로 감소하는 추세이다. 빠 른 진단 및 치료가 가장 중요하며, 조기 진단의 핵심은 환자 의 병력 및 증상파악이다. 또한 진단 및 치료 시의 의식 상태에 따라 생존률의 차이가 있는 것으로 알려져 있다.1) 영상 검사 또한 진단에 도움이 되는데 조영제 증강 뇌 자기공명영상이 가 장 좋은 진단법으로 알려져 있다. ${ }^{12,13)}$

본 증례의 경우 치성 감염으로 인해 심부 경부 감염 및 경 막하 농양이 발생한 증례였으며, 특히 치성 감염이 부비동염 등을 발생시키지 않고 두개저로 직접 전파를 통하여 경막하 농양이 유발되었다는 것이 일반적인 두개내 농양의 발생 과 정과 차이를 보이는 점이었다. 면역 저하의 과거력이 없는 건 강한 환자였다는 점 또한 보기 드문 점이었다. 국내에서는 치 성감염의 직접 전파로 경막하 농양이 발생한 증례는 보고된 바 없으며, 외국의 경우에도 소수의 증례만이 보고되어 있다. 비슷한 증례로 2001년 Shotelersuk 등 (4)은 25세 남성이 치성 감염으로 시작하여 저작근 주위 공간(masticator space) 및 익돌상악 공간(pterygomaxillary space) 농양으로 진행한 뒤 최종적으로 경막하 농양 소견을 보여 수술적 배농 및 항 생제 투여를 통해 호전된 사례를 보고하였다.

저자들은 면역 저하가 동반되지 않은 환자가 치성감염 이 후로 비부비동염 없이 발생한 경막하 농양에 대하여, 원인이 
되었던 치아의 발치 및 부인강 농양의 배농과 더불어, 전두엽 경막하 농양에 대하여 내시경을 이용한 경사골동 접근법을 이용한 배농을 시행하고, 장기간의 항생제 치료로 성공적으 로 치료된 증례를 경험하였기에 보고하는 바이다.

\section{REFERENCES}

1) Charles W Cummings, Bruce H Haughey, J Regan Thomas. Cummings Otolaryngology-Head and Neck Surgery Fourth Edition Review. Richmond, TX: Mosby;2005.

2) Gormley WB, del Busto R, Saravolatz LD, Rosenblum ML. Cranial and intracranial bacterial infections. In: Youmans JR, editor. Neurological Surgery. 4th ed. Philadelphia: WB Saunders Co.;1996. p.3191-220.

3) Brennan MR. Subdural empyema. Am Fam Physician 1995;51(1): $157-62$.

4) Tunkel AR. Subdural empyema, epidural abscess, and suppurative intracranial thrombophlebitis. In: Mandell GL, Bennett JE, Dolin R, editors. Mandell, Douglas, and Bennett's Principles and Practice of Infectious Diseases. 6th ed. Philadelphia: Elsevier Churchill Livingstone;2005. p.1165-8.

5) Kim YK, Seo SY, Kim KM, Yoon YJ. A case of subtentorial subdural empyema resulting from chronic otitis media with cholesteatoma. Korean J Otolaryngol-Head Neck Surg 1998;41(4):534-7.
6) Kim K, Lim SC. Image-guided surgery in the paranasal sinus and skull base lesion. Korean J Otolaryngol-Head Neck Surg 2006;49(11): 1082-6.

7) Stephanov S, Joubert MJ, Welchman JM. Combined convexity and parafalx subdural empyema. Surg Neurol 1979;11(2):147-51.

8) Nakao A, Choh H, Yamashita Y, Takenaka N, Okada K, Takeuchi Y. [Acute subdural abscess due to mixed infection of Eikenella corrodens and Streptococcus constellatus]. Kansenshogaku Zasshi 2001;75 (11):977-80.

9) Okayama H, Nagata E, Ito HO, Oho T, Inoue M. Experimental abscess formation caused by human dental plaque. Microbiol Immunol 2005;49(5):399-405.

10) Mauser HW, Van Houwelingen HC, Tulleken CA. Factors affecting the outcome in subdural empyema. J Neurol Neurosurg Psychiatry 1987;50(9):1136-41.

11) Haines SJ, Mampalan T, Rosenblum ML, Nagib M. Cranial and intracranial bacterial infections. In: Youmans JR, editor. Neurological Surgery. 3rd ed. Philadelphia: WB Saunders;1990:3730-1.

12) Adame N, Hedlund G, Byington CL. Sinogenic intracranial empyema in children. Pediatrics 2005;116(3):e461-7.

13) Greenlee JE. Subdural empyema. Curr Treat Options Neurol 2003; 5(1):13-22.

14) Shotelersuk V, Goyal M, Rauchenstein JN, Konez O. Subdural empyema secondary to odontogenic masticator space abscess: detection by indium-111-labeled white cell scan. Clin Imaging 2001;25(1):18-22. 